\title{
The Quality of Life of Patients with HIV/AIDS Undergoing Antiretroviral Therapy: A Systematic Review
}

\section{Putri Irwanti Sari, RTS Netisa Martawinarti, Nurmawati S. Lataima, and Vivi Meiti Berhimpong}

Faculty of Nursing, Universitas Airlangga, Surabaya, Indonesia

\begin{abstract}
Introduction: Quality of Life (QoL) is one of the most important things for a patient with HIV/AIDS. Good QoL will improve the adherence to treatment, especially antiretroviral therapy. The purpose of this study was to explore about the quality of life of the patients with HIV/AIDS undergoing antiretroviral therapy.

Methods: The data was collected through a literature review from electronic databases such as Scopus, ProQuest, Google Scholar and Springerlink journal. The keywords were "quality of life", "HIV/AIDS", "quality of life of patients with HIV/AIDS" or "quality of life and HIV/AIDS and antiretroviral therapy".

Results: The researcher obtained 15 articles based on the inclusion criteria. Several research articles that were analyzed showed that the Quality of Life of HIV/AIDS patients undergoing antiretroviral therapy was not all good. This is caused by the side-effects of using antiretroviral therapy and the side-effects that were physical, psychological, social and environmental.

Conclusion: The impact of the side effects of antiretroviral therapy has caused the clients with HIV/AIDS to choose other therapies such as ART replacement therapy to improve the quality of life for patients with HIV/AIDS
\end{abstract}

\section{ARTICLE HISTORY}

Received: Dec 26, 2019

Accepted: Dec 31, 2019

\section{KEYWORDS}

antiretroviral; HIV//AIDS; quality of life

\section{CONTACT}

Puteri Irwanti Sari

$\triangle$ putri.wanti.sari2018@fkp.unair.ac.id

$\doteq$ Faculty of Nursing, Universitas Airlangga, Surabaya, Indonesia

Cite this as: Sari, P. I., Martawinarti, R. N., Lataima, N. S., \& Berhipong, V. M. (2019). The Quality of Life of Patients with HIV/AIDS Undergoing Antiretroviral Therapy: A Systematic Review.Jurnal Ners, 14(3si), 50-54. doi:http://dx.doi.org/10.20473/in.v14i3(si).16978

\section{INTRODUCTION}

Recently, HIV infection has been considered to be a chronic disease because the effective dissemination of antiretroviral therapy has lengthened the life expectancy of people living with HIVWHO. It has been noted that since AIDS was discovered and up until the end of 2014, 34 million people had died and in 2014, 1.2 million people died of the virus. There were 36.9 million people living with HIV in the world at the end of 2014. The goal of sustainable development goals (SDG) is to stop the HIV / AIDS epidemic in the world by 2030 . In 2016, around 36.7 million people were living with HIV around the world. Indonesia was ranked as having the third largest number of people living with HIV (PLWHA) in the Asia and Pacific region (Ortblad, Lozano, \& Murray, 2013). Many HIV patients in low- and middle-income countries do not immediately start antiretroviral therapy (ART) despite being eligible for ART(Daniels et al., 2018). The results of the study by Linlin Lindayani meant that the overall WHOQOL-HIV score was 78.9 (SD = 9.08; range; 46-101). There were no significant differences in the WHOQOL-HIV domain scores at various stages of the disease after controlling for potential confounders (Lindayani, Chen, Wang, \& Ko, 2018).

Health-related quality of life (HRQoL) is a broad concept that reflects the patients' general subjective perceptions of the effects of disease or interventions on the physical, psychological and social aspects in their daily lives. HRQoL among HIV-infected patients has become an important indicator of the impact of the disease and treatment outcomes. A cross- 


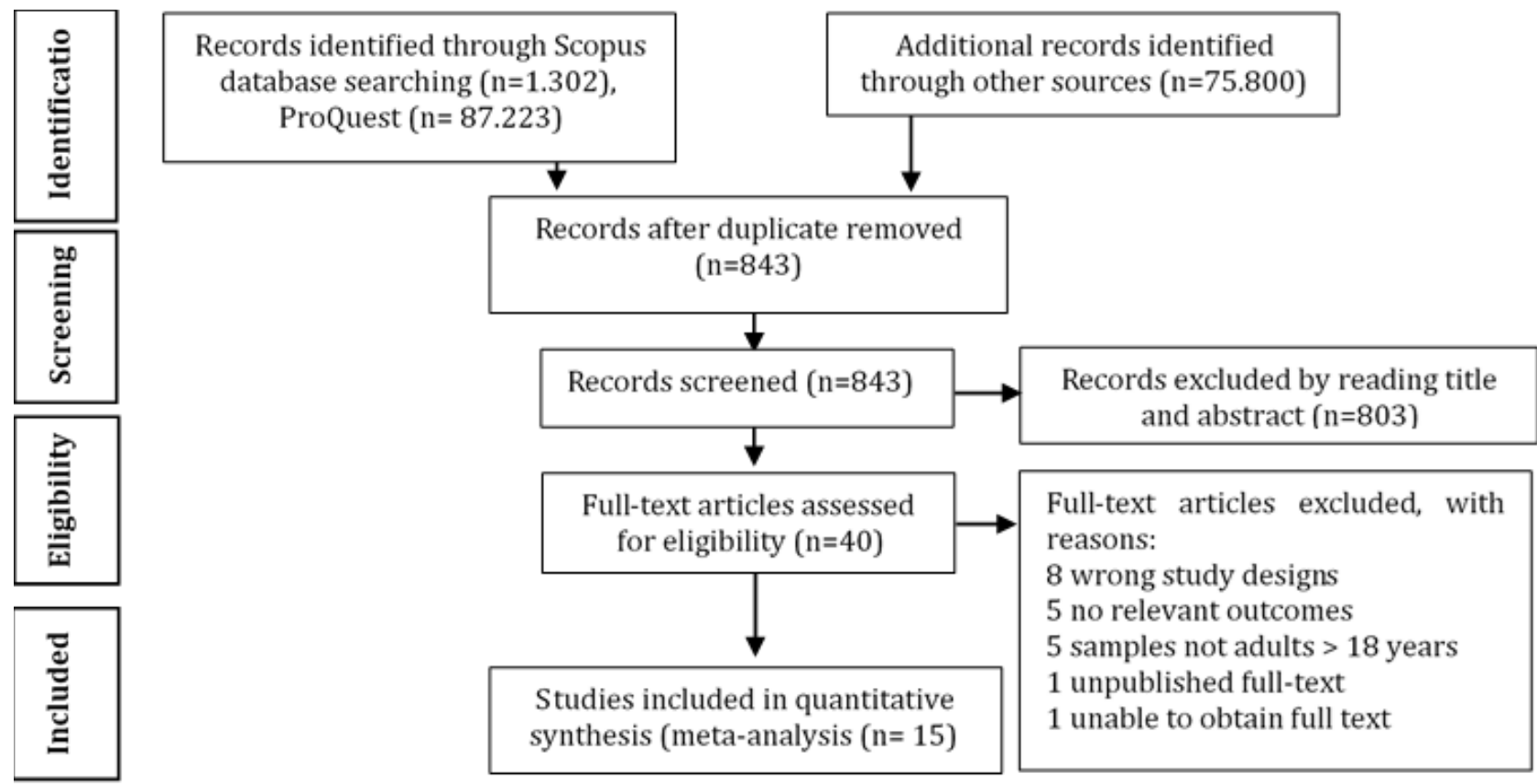

Figure 1. PRISMA

sectional survey was conducted at the Chitungwiza Central Hospital, Zimbabwe, to assess the HRQoL in patients with HIV / AIDS who received antiretroviral therapy (ART) using two validated instruments. The targeted quality of life for HIV / AIDS (HAT-QoL) and the EuroQoL Five-dimensional three-level instruments (EQ-5D-3L) were used to assess HRQoL (Mafirakureva, Dzingirai, Postma, van Hulst, \& Khoza, 2016). Therefore, it is necessary to further analyze the quality of life of patients undergoing antiretroviral therapy to determine the effects of antiretroviral therapy for patients with HIV / AIDS.

\section{MATERIALS AND METHODS}

The systematic review was conducted using a standard methodology as published by IOP Introductory guide for authors. We followed the Preferred Reporting Item for Systematic Reviews and Meta-analyses (PRISMA) guidelines. This systematic review was made in such a way to get answers about the quality of life of HIV/AIDS patient undergoing antiretroviral therapy.

The process used to conduct the systematic review involved reviewing several research articles published through electronic databases. The electronic databases used were Scopus, ProQuest, Google Scholar and SpringerLink. The keywords for the journals in English were "Quality of life", "HIV/AIDS", "Quality of life of patients with HIV/AIDS" or "Quality of life and HIV/AIDS and antiretroviral therapy". The search results found in ProQuest totaled 87.223 journals, and Scopus had 1,302 journals and Google Scholar had 75,800 journals so the total journals found were 164.325. The journals found were specified based on the inclusion criteria. After adjusting for the inclusion criteria, the missing articles made up 843 documents. We then selected the same article (duplicate article) published from Scopus, ProQuest and SpringerLink, selected based on the suitability of the article title with the aim of systematic review. We then filtered based on the research where one of the samples in the study must be adults or couples $>18$ years; 40 articles were then obtained. Of the 40 articles selected, 15 were analyzed.

Studies meeting the following criteria were included in the systematic review: (1) full-text articles published in English, (2) research articles from the period 2013-2018, (3) different types of quantitative research, (4) articles where the main content was HIV/AIDS patients undergoing antiretroviral therapy and (5) the samples in the study must be adults or couples $>18$ years. The exclusion criteria in the systematic review were (1) a wrong study design, (2) no relevant outcomes and (3) unpublished full-text or unable to obtain the full text.

\section{RESULTS}

The total respondents in this review were 45,377 people with the disease (HIV/AIDS) who received antiretroviral therapy. The area in this study was hospitals and communities. Of the 15 articles selected, research was conducted in Indonesia, South Africa (KwaZulu-Natal, Cape Town), Botswana, the Republic of Zimbabwe, Zambia, Ethiopia, India and Kenya. All of the articles analyzed according to the type of research are quantitative approaches $(n=15)$.

The most widely used research design was correlation with a cross-sectional approach $(n=13)$ and a prospective cohort $(n=2)$. In connection with the year of publication, the research articles were published in the range of 2013-2018. All of the samples in the study were HIV / AIDS patients who were on antiretroviral therapy (ART). The most 
Table 2. Studies that formed the basis of the systematic review

\begin{tabular}{|c|c|c|c|c|}
\hline Author & Type of Study & Respondents & Instrument & Outcome \\
\hline $\begin{array}{lr}\text { Maiese, } & \text { Johnson, } \\
\text { Bancroft, } & \text { Goolsby } \\
\text { Hunter, \& Wu, 2016) }\end{array}$ & Cohort study & 134 clients with HIV & $\begin{array}{l}\text { MOS-HIV } \\
\text { DASS-21 } \\
\text { HIV TSQs }\end{array}$ & $\begin{array}{l}\text { The patient has improved an } \\
\text { quality of life after replacing the } \\
\text { antiretroviral therapy regimen }\end{array}$ \\
\hline (Lindayani et al., 2018) & Epidemiology & 215 respondents & WHOQOL-BREF & $\begin{array}{l}\text { The main priority was the sleep } \\
\text { problem } \\
\text { ART can improve quality of life }\end{array}$ \\
\hline $\begin{array}{l}\text { (Mafirakureva et al., } \\
\text { 2016) }\end{array}$ & Epidemiology & $\begin{array}{l}257 \text { clients with } \\
\text { HIV/AIDS }\end{array}$ & $\begin{array}{l}\text { HRQoL HAT-QoL } \\
\text { EQ-5D-3L } \\
\text { Euro QoL } \\
\text { VAS }\end{array}$ & $\begin{array}{l}\text { Higher levels of HRQoL are } \\
\text { positively and significantly } \\
\text { related to income, education } \\
\text { and employment. }\end{array}$ \\
\hline $\begin{array}{l}\text { (Munene \& Ekman, } \\
\text { 2014) }\end{array}$ & Epidemiology & 421 clients with HIV & $\begin{array}{l}\text { SF-36 HRQol } \\
\text { PCS }\end{array}$ & $\begin{array}{l}\text { Antiretroviral therapy is } \\
\text { negatively related to HRQoL }\end{array}$ \\
\hline 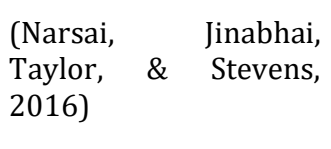 & Descriptive & 600 respondents & $\begin{array}{l}\text { EQSD } \\
\text { EQ-VAS }\end{array}$ & $\begin{array}{l}\text { Use of antiretroviral therapy } \\
\text { The majority of the } \\
\text { respondents were young } \\
\text { women }\end{array}$ \\
\hline $\begin{array}{l}\text { (Ndubuka, Lim, Ehlers, } \\
\text { \& Van Der Wal, 2017) }\end{array}$ & Descriptive & $\begin{array}{l}456 \text { HIV clients on } \\
\text { ART }\end{array}$ & $\begin{array}{l}\text { WHOQoL-HIV- } \\
\text { BREF }\end{array}$ & $\begin{array}{l}\text { The domain of the environment } \\
\text { got the lowest score } \\
\text { The Quality of life for PLWHA is } \\
\text { bad }\end{array}$ \\
\hline (Nglazi, 2014) & Descriptive & $\begin{array}{l}903 \text { HIV clients on } \\
\text { ART }\end{array}$ & $\begin{array}{l}\text { HRQOL } \\
\text { EQ-5D } \\
\text { EQ-5D-VAS }\end{array}$ & $\begin{array}{l}\text { There is no significant } \\
\text { relationship between the } \\
\text { groups for most Eq-5D domains }\end{array}$ \\
\hline $\begin{array}{l}\text { (Amanuel, } \\
\text { Mulusew, \& Hailay, } \\
\text { 2015) }\end{array}$ & Descriptive & $\begin{array}{l}494 \text { HIV clients on } \\
\text { ART }\end{array}$ & WHOQOL- BREF & $\begin{array}{l}\text { Family support for the clients } \\
\text { with low ART }\end{array}$ \\
\hline (Thomas et al., 2017) & Descriptive & $\begin{array}{l}38691 \text { respondents, } \\
19750 \text { from Zambia, } \\
\text { and } 18941 \text { from } \\
\text { South Africa }\end{array}$ & $\begin{array}{l}\text { HRQOL } \\
\text { EQ-5D-5L }\end{array}$ & $\begin{array}{l}\text { HRQOL } \\
\text { There is no difference between } \\
\text { HIV-positive and HIV-negative } \\
\text { HRQoL }\end{array}$ \\
\hline $\begin{array}{l}\text { (Tomita, Garrett, } \\
\text { Werner, } \\
\text { Mpanza, et al., 2014) }\end{array}$ & Cohort & $\begin{array}{l}160 \text { clients with } \\
\text { HIV/AIDS }\end{array}$ & FAHI & HRQoL increases \\
\hline $\begin{array}{l}\text { (Tomita, Garrett, } \\
\text { Werner, } \quad \text { Burns, } \\
\text { Ngcobo, et al., 2014) }\end{array}$ & Cohort & $\begin{array}{l}160 \text { clients with ART } \\
\text { cohorts (n=51 and } \\
\text { non-initiating ART } \\
(n=191)\end{array}$ & $\begin{array}{l}\text { HRQoL } \\
\text { FAHI }\end{array}$ & $\begin{array}{l}\text { Non-initiation ART HRQoL was } \\
\text { higher than cohort ART }\end{array}$ \\
\hline (Vo et al., 2016) & Descriptive & $\begin{array}{l}1180 \text { clients with } \\
\text { HIV }\end{array}$ & $\begin{array}{l}\text { HAT-QOL } \\
\text { HRQOL }\end{array}$ & Low life satisfaction \\
\hline $\begin{array}{l}\text { (Torres, Harrison, La } \\
\text { Rosa, Lavenberg, et al., } \\
2018 \text { ) }\end{array}$ & Descriptive & 512 clients with HIV & QoL Based & $\begin{array}{l}\text { Quality of Life } \\
\text { There is ART failure } \\
\text { Compliance with treatment } \\
\text { Decreasing the virus load }\end{array}$ \\
\hline $\begin{array}{l}\text { (Torres, Harrison, La } \\
\text { Rosa, Cardoso, et al., } \\
\text { 2018) }\end{array}$ & Descriptive & 512 clients with HIV & QoL Based & Quality of life can be improved \\
\hline $\begin{array}{l}\text { (Pokhrel, Gaulee } \\
\text { Pokhrel, Neupane, \& } \\
\text { Sharma, 2018) }\end{array}$ & Descriptive & $\begin{array}{l}682 \text { clients using } \\
\text { ART }\end{array}$ & $\begin{array}{l}\text { WHOQOL-HIV- } \\
\text { BREF Scale }\end{array}$ & $\begin{array}{l}\text { Compliance } \\
\text { treatment } \\
\text { QOL }\end{array}$ \\
\hline
\end{tabular}

widely used research instruments when assessing the quality of life of patients with HIV / AIDS was the Euro Quality of Life Instrument, the Functional Assessment of HIV Infection (FAHI) Instrument, WHOQoL-HIV BREF, Euro Quality Visual Analog Scale (EQ-5D VAS), HAT -QoL, HRQoL (EQ 5D), MOS-HIV, DASS-21, HIV TSQs, others use WHOQOL-BREF, HRQL SF 36, MCS, and PCS. Several of the research articles that were analyzed showed that the Quality of Life of HIV/AIDS patients undergoing antiretroviral therapy was not good across the board. This is caused by the side effects of using antiretroviral therapy and the side effects include physical, psychological, social and environmental factors. The impact of the side effects of antiretroviral therapy has caused the clients with HIV/AIDS to use other therapies such as Nucleoside reverse transcriptase inhibitor (NRTI) replacement to Non-Nucleoside reverse transcriptase inhibitor (NNRTI) therapy to improve the quality of life for patients with HIV/AIDS.

\section{DISCUSSION}

The systematic review of the quality of life of patients with HIV/AIDS who are undergoing antiretroviral therapy is very necessary to improve their understanding of the quality of life of patients as the most widely used instruments. The factors that affect 
quality of life and the complaints most often felt by patients can be the input for medical personnel including nurses in improving the quality of life of patients undergoing antiretroviral therapy. Besides that, it also helps other medical personnel to collaborate to improve the patients' quality of life.

Some articles show that the patients experience problems when using antiretroviral therapy. This can affect the quality of life of the patients. Quality of life is the concept of the analysis of individuals to get a normal life related to the individual perceptions of the goals, expectations, standards and special attention to life experienced by being influenced by cultural values in the individual environment. There are four domains that are used as parameters to determine quality of life, and each domain is described in several ways: the physical health domain, psychological domain, social relations domain and environmental domain.

Good quality of life will improve the adherence to therapy. Adherence is very important in antiretroviral treatment because if the drug do not reach the optimal concentration in the blood, then it allows for the development of resistance. Taking the medication doses on time and correctly can prevent resistance. Level of adherence is highly correlated with the success of maintaining viral suppression. Things that must be considered are the reduction of mutations and resistance. HIV has a unique mutation characteristic. The virus can double to 1 billion per day. For people on ART, if they are not adherent to the treatment, then the virus can multiply and there will be a choice of resistant HIV types. The only way to prevent mutations is to suppress the complete multiplication of the virus which ensures that no new mutants are produced.

For resistance in the NNRTI group, only one HIV mutation makes the patient resistant to all drugs in one class, while the other ARV class requires several mutations to become resistant. In the case of failed therapy, second-line regimens should replace NNRTIs with Protease inhibitors (PI) such as Nelfinavir (NFV), Indinavir (IDV), squinavir (SQV) and Loponavir/Ritonavir $(\mathrm{LPV} / \mathrm{r})$. Nurses need to monitor the successes and failures of the therapy, which also affects the quality of life of patients with HIV. There are times when the patient and the accompanying doctor must revise the therapy that has been done so far. There is a critical moment when the therapy for PLHIV patients must be replaced. Regarding the reasons for drug replacement, virological failure and drug resistance are characterized by an increased viral load, drug toxicity, patient tolerance and non-compliance with treatment. The more often that patients change their treatment, for example due to therapy failure, the more often it is that the success rate of the next regimen will be lower than the previous regimen. The probability of success is lower than the previous regimen. The best treatment success in the first regimen is determined by the $4 \mathrm{Ss}$, namely Start, Substitute, Switch and Stop.

\section{CONCLUSION}

Various countries have examined the quality of life of HIV/AIDS patients undergoing antiretroviral therapy and the results of their research show that not all of the patients' quality of life is good. This was due to the side effects of the antiretroviral therapy. Therefore the clients with HIV choose to use other therapies as ART replacement therapy to improve their quality of life with HIV/AIDS. We found that HIV patients whose regimen was switched due to treatment-related sideeffects experienced an improvement in QoL. Further research is needed on the effects of ART and ART replacement therapy and into the client's experience with ART on quality of life. The findings in this study suggest that physicians should take the potential impact of QoL into consideration when making decisions on a switch in ART regimen, particularly when the patients are intolerant of their current treatment.

\section{REFERENCES}

Amanuel, T., Abebe, G., Mulusew, G., \& Hailay, A. (2015). Gender Differences in Health Related Quality of Life among People Living with HIV on Highly Active Antiretroviral Therapy in Mekelle Town, Northern Ethiopia. BioMed Research International, 2015(Article ID 516369), 1-9. https://doi.org/http://dx.doi.org/10.1155/2015 /516369

Daniels, J., Marlin, R., Medline, A., Wilson, G., Rosengren, L., Huang, E., \& Klausner, J. D. (2018). Getting HIV Self-Test Kits into the Home for Young African American MSM in Los Angeles: A Qualitative Report. Journal of the Association of Nurses in AIDS Care, 29(1), 115-119. https://doi.org/10.1016/j.jana.2017.09.015

Lindayani, L., Chen, Y. C., Wang, J. Der, \& Ko, N. Y. (2018). Complex Problems, Care Demands, and Quality of Life Among People Living With HIV in the Antiretroviral Era in Indonesia. Journal of the Association of Nurses in AIDS Care, 29(2), 300-309. https://doi.org/10.1016/j.jana.2017.10.002

Mafirakureva, N., Dzingirai, B., Postma, M. J., van Hulst, M., \& Khoza, S. (2016). Health-related quality of life in HIV/AIDS patients on antiretroviral therapy at a tertiary care facility in Zimbabwe. AIDS Care Psychological and Socio-Medical Aspects of AIDS/HIV, 28(7), 904-912. https://doi.org/10.1080/09540121.2016.11736 39

Maiese, E. M., Johnson, P. T., Bancroft, T., Goolsby Hunter, A., \& Wu, A. W. (2016). Quality of life of HIV-infected patients who switch antiretroviral medication due to side effects or other reasons. Current Medical Research and Opinion, 32(12), 2039-2046. https://doi.org/10.1080/03007995.2016.12277 76

Munene, E., \& Ekman, B. (2014). Does duration on antiretroviral therapy determine health-related quality of life in people living with HIV? A cross- 
sectional study in a regional referral hospital in Kenya. Global Health Action, 7(1). https://doi.org/10.3402/gha.v7.23554

Narsai, P., Jinabhai, C. C., Taylor, M., \& Stevens, F. (2016). The Health Related Quality of Life of HIV Positive Respondents on Antiretroviral Treatment and HIV Negative Living in Lower Socio-Economic Housing in KwaZulu-Natal, South Africa. Social Indicators Research, 127(2), 851-863. https://doi.org/10.1007/s11205-015-0970-1

Ndubuka, N. O., Lim, H. J., Ehlers, V. J., \& Van Der Wal, D. M. (2017). Health-related quality of life of patients on antiretroviral treatment in Botswana: A cross-sectional study. Palliative and Supportive Care, 15(2), 214-222. https://doi.org/10.1017/S1478951516000638

Nglazi, M. D. W. S. J. D. J. A. L. N. S. L. E. V. (2014). Quality of life in individuals living with HIV/AIDS attending a public sector antiretroviral service in Cape Town, South. BMC Public Health; 2014, 14(676).

Ortblad, K. F., Lozano, R., \& Murray, C. J. L. (2013). The burden of HIV: Insights from the global burden of disease study 2010. Aids, 27(13), 2003-2017. https://doi.org/10.1097/QAD.0b013e328362ba 67

Pokhrel, K. N., Gaulee Pokhrel, K., Neupane, S. R., \& Sharma, V. D. (2018). Harmful alcohol drinking among HIV-positive people in Nepal: an overlooked threat to anti-retroviral therapy adherence and health-related quality of life. Global Health Action, 11(1). https://doi.org/10.1080/16549716.2018.14417 83

Thomas, R., Burger, R., Harper, A., Kanema, S., Mwenge, L., Vanqa, N., ... Hughes, E. (2017). Differences in health-related quality of life between HIV-positive and HIV-negative people in Zambia and South Africa: a cross-sectional baseline survey of the HPTN 071 (PopART) trial.
The Lancet Global Health, 5(11), e1133-e1141. https://doi.org/10.1016/S2214-109X(17)303674

Tomita, A., Garrett, N., Werner, L., Burns, J. K., Mpanza, L., Mlisana, K., ... Karim, S. S. A. (2014). Healthrelated quality of life dynamics of HIV-positive South African women up to ART initiation: Evidence from the CAPRISA 002 acute infection cohort study. AIDS and Behavior, 18(6), 11141123. https://doi.org/10.1007/s10461-0130682-y

Tomita, A., Garrett, N., Werner, L., Burns, J. K., Ngcobo, N., Zuma, N., ... Abdool Karim, S. S. (2014). Impact of antiretroviral therapy on health-related quality of life among South African women in the CAPRISA 002 acute infection study. AIDS and Behavior, 18(9), 1801-1807. https://doi.org/10.1007/s10461-014-0800-5

Torres, T. S., Harrison, L. J., La Rosa, A. M., Cardoso, S. W., Zheng, L., Ngongondo, M., ... Hughes, M. D. (2018). Quality of life improvement in resourcelimited settings after one year of second-line antiretroviral therapy use among adult men and women. Aids (Vol. https://doi.org/10.1097/QAD.00000000000017 38

Torres, T. S., Harrison, L. J., La Rosa, A. M., Lavenberg, J. A., Zheng, L., Safren, S. A., ... Hughes, M. D. (2018). Quality of life among HIV-infected individuals failing first-line antiretroviral therapy in resourcelimited settings. AIDS Care, O(0), 1-9. https://doi.org/10.1080/09540121.2018.14272 07

Vo, Q. T., Hoffman, S., Nash, D., El-Sadr, W. M., Tymejczyk, O. A., Gadisa, T., ... Elul, B. (2016). Gender Differences and Psychosocial Factors Associated with Quality of Life Among ART Initiators in Oromia, Ethiopia. AIDS and Behavior, 20(8), 1682-1691. https://doi.org/10.1007/s10461-016-1396-8 